\title{
The Innovative Approach for Accounting and Accountability of Government Revenues in $\operatorname{Iraq}^{(1)}$
}

\author{
Dr. Talal A. Al- Kassar ${ }^{1 *}$ Prof. Dr. Mahmoud Al-Wadi ${ }^{2}$ Dr. Alexander Dawoody ${ }^{3}$ \\ 1. Department of Accounting, Faculty of Economics and Administrative Sciences, Zarqa University \\ P.O. Box 132222, Zarqa 13110, Jordan. \\ 2. President of Zarqa University, Secretary General of the quality for high education, Zarqa University \\ P.O. Box 132222, Zarqa 13110, Jordan. \\ 3. Administrative Studies Faculty, President of Association for Middle Eastern Public Policy and \\ Administration (AMEPPA), Marywood University, 2300 Adams Avenue, Scranton, PA 18509 USA. \\ Email:talal_kassar@yahoo.com
}

\begin{abstract}
This study indicates that accountability of government revenue procedures are sufficient, adequate, and well developed and illustrates new control bodies that parliament has created (such as the Commission of Integrity) in addition to the Board of Supreme Audit (BSA) to fight financial and managerial corruption. It covers both theoretical and empirical aspects. The theoretical side includes literature review, defining the accountability, audit of revenues, performance audit, taxation policy, and the sources of governmental income. While the empirical side includes studying the economic influence of government revenues in Iraq, different sources of government income, governmental control bodies, and the auditing procedures used by the BSA.This research considers how the contribution of oil revenue and tax revenues can be measured. It shows that the Iraqi Government depends almost totally on oil revenues (about $93 \%$ in 2012). The situation has deteriorated since 2003, when Iraq was first occupied, in spite of increased revenue from taxation. The Study highlights that the State should increase its role from different organizations to control all expenditures and develop revenue streams in other sectors. Although there is an emphasis on financial and budgetary measures for financial accountability, the use of non-financial measures in determining outcome accountability is increasing.
\end{abstract}

Keywords: Government, Revenues, Accountability, Audit, Control Bodies, Innovation.

\section{Introduction}

In Iraq, accountability of revenue audit, as an important domain of public auditing, has been engaging the attention of the Board of Supreme Audit (BSA) and in other institutions (namely the Commission of Integrity and the Inspector General of each ministry) for quite some time. Normally, the Ministry of Finance has its own financial control on its directorates especially for revenues and expenditures. While the Commission of Integrity was linked to parliament for special duty, which is related to financial and managerial corruption, and submitted their reports to the Justice Ministry and to the Integrity Committee at the parliament for big corruption. While government revenues are derived from two sources, tax receipts and non-tax receipts, the major source of national revenues are tax receipts raised through fiscal statutes.

The taxation policy of a government generally seeks to apply the following desirable fiscal principles (ASOSAI report, 2010: 2):

(a) The subjects of every State ought to contribute to the support of the Government as nearly as possible in proportion to their respective abilities; that is, in proportion to the revenue which they respectively enjoy under the protection of the State. The observation or neglect of this maxim reflects what is called the equality or inequality of taxation.

(b) The tax which each individual is bound to pay ought to be certain and not arbitrary. The time of payment, the manner of payment, the quantity to be paid, ought all to be clear and plain to the contributor, and to every other person.

(c) Every tax ought to be levied at the time, or in the manner, in which it is most likely to be convenient for the contributor to pay it.

(d) Every tax ought to be so contrived as both to take out and keep out of the pockets of the people as little as possible over and above what it brings into the public treasury of the state.

Most developing countries are interested in governmental revenues, because they have a great role and provide the means to build the required and right economic base. Developing countries are, therefore, looking to increase their revenues from different sources. It is important to find the best method to control these revenues and achieve the necessary development in different fields that the government wishes to support. A new approach to building economic and social infrastructure emerged at the end of the twentieth century and this is related to the privatization of public projects. This has been tried in fully developed nations and is also relevant in developing

(1)"This research is funded by the Deanship of Research and Graduate Studies in Zarqa University /Jordan" 
countries. Whilst privatization provides a basis to resource more development, auditing bodies still need to address accountability and audit of the use of public funds. This might increase their revenues, but this situation still required more attention from the high auditing institutions to continue their control (accountability and audit) because of their ratio in tax revenues.

In summary, the main concern of a modern state is to provide services to its citizens and lead the country on the path toward development. The state can discharge its duties only if sufficient resources are at its command. These resources are generated through various government revenues. The research has been carried out, in one of the developing countries, namely Iraq, according to two reasons. The first was the rapid dependence of this country on oil revenues and an emergence of foreign investment in different sectors. Second was the new direction of democratic regime since 2003, including elections, central, province and local governments and effective parliament.

The objectives, problems, and scope and methodology of this research are below:

\subsection{Research Objectives}

The research seeks to realize the following objectives:

1. To measure the State's dependence on oil revenues relative to others.

2. To develop and increase dependence on other revenues.

3. To highlight and to ensure that auditing of governmental revenue in Iraq is sufficient.

1.2 Research Problem Statement

The research problem focuses on how can the researcher measure the contribution of oil revenue and tax revenues to government revenues in Iraq and the accountability and audit to governmental revenues and their percentage of total revenues.

1.3 Methodology

The research paper will cover both theoretical and empirical materials. The theoretical side defines the accountability, audit revenues, performance audit, taxation policy and the kinds of governmental revenues. While the empirical side includes studying the economic influence of government revenues through real figures from Iraq to different types of government revenues and the auditing procedures by the Board of Supreme Audit. Different materials, articles, reports, and sites have been used to assist the research paper. Thus the proposed paper attempts:

1. To show varying sources of governmental revenues.

2. To define the auditing procedures control bodies.

3. To link the legislation related to government revenues.

Therefore, the research will present, in brief, the subject from researcher's point of view. Thus, the paper seeks to fill this important gap in the literature by exploring the need of accountability of government revenues in particular taxes.

The paper is organized as follows: the next section provides a review of literature. Section three begins by overview of the meaning of accounting and accountability including internal and external indicators. Section four presents types of government revenues. Section five presents control bodies, audit planning, auditing methods of government revenues, and human resource management. Section six includes discussion. Finally section seven includes findings, limitation, further studies and conclusions.

\section{Literature Review}

The audit process is superimposed on an accountability framework. A traditional definition of accountability is the obligation to answer for a responsibility conferred. This definition often is interpreted as implying two distinct and often unequal partners: one who confers and the other who is obliged to answer. In so doing, it does not reliably address several realities in today's public management. These include (OAG, 2005: 16):

- The emergence of alternative delivery approaches, such as arrangements between the federal and provincial governments, where responsibilities may not be conferred from a senior party to a junior one, but agreements nonetheless assume accounting for results;

- The call for a much increased focus on performance-based management and results in public sector; and

- The importance of transparency as an essential feature of public sector accountability.

Beechy (2007) mentioned in his study that "a different concept of accountability is embodied in the Canadian accounting standard on non-profit organizations (NPO) accounting" (p. 4). The CICA Handbook emphasizes the purpose of the statement of operations, section 4400 :

...provides information about the cost of the organization's service delivery activities for the period and the extent to which these expenses were financed or funded by contributions and other revenue. The information provided in the statement of operations is useful in evaluating the organization's performance during the period, including its ability to continue to provide services, and in assessing how the organization's management has discharged its stewardship responsibilities." 
In recent years, many studies [Pollitt (1993), Kloot (1999), Barton (2000), Gendron, Cooper, and Townley (2001), Earl (2005), and Beechy (2007)] have been conducted in different countries in the area of accountability and auditing. Some of these studies investigated the role of accounting and accountability. Others studies focus on audit and accountability. Kloot (1999) uncovers a great deal of literature on performance measurement and accountability in government. Governments around the world have invested large amounts to develop performance measurement systems - the results of which are mediocre, at best. There is also a growing recognition that financial performance measures alone measure only limited aspects of an organization's performance. In order to improve performance measurement systems and accountability to different stakeholders, non-financial indicators have been developed for the for-profit sector. Prior research in the local government sector in the state of Victoria, Australia, showed low levels of accountability and very little performance measurement taking place. However, significant changes have been imposed on the sector, enhancing local and central accountability, making it more business-like and focusing on the need to measure performance.

This research studied the extent to which performance measurement systems are currently being used in practice in Victorian local government, the factors which lead to the use of performance measurement, and the extent of non-financial indicators. The results revealed a substantial increase in the level of use of performance measurement in the sector, which is related to increased emphasis on accountability and organizational changes imposed on the sector by the state government. The performance of both people and programs is now being measured. Although there is an emphasis on financial and budgetary measures for financial accountability, the use of non-financial measures in determining outcome accountability is increasing. Customer service and quality are two of the areas in which non-financial performance measures are being developed.

Barton (2000) notes that investigation of public heritage facilities - national parks, art galleries, and museums and so on - are now required by professional accounting standards in Australia to be valued and included in government general purpose financial statements as assets. The article explains the nature and significance of public goods and how they differ from private goods. It explains why commercial accounting principles are irrelevant for public heritage facilities because their objectives are social rather than financial and why commercial valuations are irrelevant and unreliable if applied to them. Finally, it is contended that the facilities are assets held in trust for the nation by government and hence should not be included in its general purpose financial reports.

While Gendron et al. (2001) investigate the role of the state auditor in Alberta. An analysis of the Office of the Auditor General of Alberta's annual reports shows that the role of the Office has significantly changed to promote and encourage the implementation in the public sector of a particular type of accountability informed by new public management. The authors argue that the Office has increased its power to influence politicians and public servants about the merits of its specific understanding of what accountability should be. However, as the Office becomes more powerful, it also becomes more vulnerable to complaints about a lack of independence from the executive. Indeed, the Office is now so closely associated with new public management that we believe that it is difficult for the Office to sustain the claim that it is able to provide independent assessments of publicsector administration.

\section{Accounting and Meaning of Accountability}

Much of the accounting literature assumes that accounting and financial reporting in a country is a function of its environment (Elsayed \& Hoque, 2010). Accounting, performance auditing, and accountability can be considered as those parts of the formalized information used by the organizations of state to influence the behavior of their managers that leads to the attainment of organizational objectives. Accounting is gathering, organizing and reporting information that describes performance (Earl \& LeMahieu, 1997). A performance audit is a systematic, purposeful, organized, and objective examination of government activities. It provides parliament with an assessment on the performance of these activities based on information, observations, and recommendations designed to promote accountable government, an ethical and effective public service, good governance, sustainable development and the protection of the state's legacy and heritage (OAG, 2005: 13).

In light of these new realities, a restatement of the underlying principles, practices and tools of accountability, which incorporates the traditional definition, could be as follows: a relationship based on obligation to demonstrate and take responsibility for performance in light of agreed upon expectations. In this view, accountability is about the requirement to answer for what you have or have not accomplished that is of significance and value. This restatement implies that accountability does not require hierarchical relationships, since there is no necessary "conferring" taking place. Accountability is rather seen to be assumed and/or agreed to by each party in a recognized accountability relationship, even when one party does indeed delegate responsibilities to the other, as in the traditional case.

(The highlighted sections are exact copies of parts of previous sections in the article. The author used it here; therefore, all editing done on the previous section was done in the highlighted section. Editor did not remove or alter for lack of knowledge of what meaning the author was attempting to convey.) 
Earl (2005) has highlighted that accountability and data are the heart of contemporary reform efforts worldwide. Accountability has become the watchword of education, with data holding a central place in the current wave of large-scale reform. The statutory role of the auditors is to provide the management with independent and objective assurance on the reliability of financial statements and of certain other information provided by the organization. However, auditing of government revenues play an important role in decision making. In particular, a fundamental use of accounting information is to help several parties make an effective decision concerning their investment portfolios. This is a vital role of accountability which is the conversation about what the information means, how it fits with everything else known, and how to use it to make positive changes (Earl \& LeMahieu, 1997).

Pollitt (1993) has noted that the issue of consultant accountability for decisions remains unresolved, and consequently, attempts to identify the role of audit, and the issue of clinical quality, in the wider context of changing attitudes and policies toward professionally-provided public services in general. The focus here will be on audit in secondary and tertiary settings, although Pollitt believes that most of the points made are also applicable to general practice.

Accountability is the current mantra both for non-profit organizations and for government (Beechy, 2007). There is a wide range of definitions to accountability. A few of the many definitions that can be found on the internet are as follows: (more details could be found in Beechy):

1. Accountability has several meanings and is the subject of a broad debate in American governance. Some of the simpler definitions include: responsibility or capable of being held responsible for something: capable of being explained: being held to count, scrutinized, and being required to give an account or explanation. en.wikipedia.org/wiki/Accountability

2. Accountability is the capacity to account for one's action; or as a representative of one's organization, to account for either your actions or the actions of your organization. The term is usually used in the voluntary sector to refer to the responsibility a non-profit organization has to inform donors of the manner in which their gifts were used. envision.ca/templates/profile.asp?ID $=56$

3. The responsibility of program mangers and staff to provide evidence to stakeholders and funding agencies that a program is effective and in conformance with this coverage, service, legal, and fiscal requirements.

www.crc.gov/tobacco/evaluation_manual/glossary.html

4. The obligation to demonstrate and take responsibility for performance in light of agreed expectations. There is a difference between responsibility and accountability: responsibility is the obligation to act; accountability is the obligation to answer for action.

www.hrsdc.gc.ca/en/cs/fas/as/sds/appd_sds03.shtml

Although the context and wording of these definitions vary considerably, their overall sense is that managers are responsible for explaining their actions to outsiders, whether to funders, donors, clients, or the community at large.

Perks \& Glendinning (1981) have shown in their paper that: "Accountability in the private sector is based on conventional financial accounts with emphasis on profit, while, public concern with aspects other than profitability alone such as social performance" (p. 22). Therefore, performance indicators can play an important role in government revenue - namely in protection of the public. Thus, (Kloot, 1999) noted the following.

...there is a great deal of literature on performance measurement and accountability in government. Governments around the world have invested large amounts to develop performance measurement systems, the results of which are mediocre at best. There is also a growing recognition that financial performance measures alone measure only limited aspects of an organization's performance. To improve performance measurement systems and accountability to different stakeholders, non-financial indicators have been developed for the for-profit sector (p.565).

However, Barton's study (Barton, 2000) talks about,

... the nature and significance of public goods and how they differ from private goods. It explains why commercial accounting principles are irrelevant for public heritage facilities because their objectives are social rather than financial and why commercial valuations are irrelevant and unreliable if applied to them (p. 219). While Gendron et al. (2001) posit the role of management has significantly changed to promote and encourage the implementation of a particular type of accountability informed by new management in the public sector.

In Iraq, in general has two accounting systems (on annual basis): one for government directorates (nonprofit organizations) namely governmental accounting system, and the other one is unified accounting system (UAS) for profit organizations. Ministry of finance is responsible of the first one, while the board of supreme audit (BSA) is pursuit of the second one. This promotes the control of these expenditures through instructions and 
regulations issued by the Ministry of Finance and other regulatory authorities. The information is a corner stone by which executing is done as intended. It is an attempt to evaluate the government revenues in meeting the demand of users of the system. Therefore, BSA is responsible to audit the outcome of two systems in organizations and issue its repot according to that. In light of these new realities, a restatement of the underlying principles, practices and tools of accountability, which incorporates the traditional definition, could be: a relationship based on obligation to demonstrate and take responsibility for performance in light of agreed upon expectations. Therefore, performance indicators can play an important role in government revenues - namely in protection of the public. In order to improve performance measurement systems and accountability to different parties, non-financial indicators have been developed for the for-profit sector. As there is also a growing recognition that financial performance measures alone measure only limited aspects of an organization's performance. Thus, Board of Supreme Audit (BSA) has used both financial and non-financial indicators in the performance evaluation reports. This includes two main groups of indicators which cover the meaning of accounting and accountability as an innovation model from the BSA in Iraq. These groups of indicators are outlined below (the BSA Report: 1994):

1-Internal Indicators

The indicators which can cover the information from inside the project (whether are in production or service) and this include:

i. Production indicators.

ii. Productivity indicators.

iii. Financial Indicators.

iv. Marketing indicators.

v. Personnel indicators

vi. Special Indicators, (which related to the nature of the project).

\section{2- External indicators}

The indicators, which can cover the information of economic, social, political and environmental, for a project and the extent of their effect on the results, this includes:

vii. Economic indicators

viii. Social indicators

ix. Political indicators

x. Environmental Indicators.

Thus, all performance evaluation reports contain most of the indicators. The results revealed a substantial increase in the level of use of performance measurement in the governmental sector, related to increased emphasis on accountability and organizational changes imposed government. Although there is an emphasis on financial measures for financial accountability, the use of non-financial measures in determining outcome accountability is also increasing.

\section{Types of Government Revenues}

The State does not depend on a single source of revenue, there are several revenue streams that the State exploits to raise funds. These sources vary widely and are developed over time under the influence of political and economic forces in operation. The governmental revenues in Iraq can be classified as follows:

i) Oil revenues: make a large contribution to the state budget.

ii) Taxes:

a- Direct taxes (like income tax, wealth tax, agriculture income and estates taxes including corporations and companies taxes).

b- Indirect taxes (like commodity taxes, customs and other dues).

iii) Revenues of the state enterprises (like the governmental enterprises revenues, capital revenues, revenues of selling and renting state properties, and other revenues).

Table 1 provides an overview of tax revenues as a percentage of GDP which classified by revenue sources as a percentage of total revenue.

Table (1) Tax revenue as a percentage of total revenue

\begin{tabular}{|c|c|c|c|c|c|}
\hline & \multirow{2}{*}{$\begin{array}{l}\text { Tax revenue as percentage } \\
\text { of G.D.P. }\end{array}$} & \multicolumn{4}{|c|}{ Revenue sources as percentage of total revenue } \\
\hline & & $\begin{array}{l}\text { Direct } \\
\text { taxes }\end{array}$ & $\begin{array}{l}\text { Indirect } \\
\text { taxes }\end{array}$ & $\begin{array}{l}\text { Trade } \\
\text { taxes }\end{array}$ & $\begin{array}{l}\text { Others (including Oil } \\
\text { revenue) }\end{array}$ \\
\hline $\begin{array}{ll}\text { Developing } & \text { countries } \\
\text { (average) * } & \end{array}$ & 18.5 & 29.7 & 28.1 & 27.6 & 14.6 \\
\hline $\operatorname{Iraq}(1993) * *$ & 2.3 & 40.5 & 9.7 & 0 & 49.8 \\
\hline $\operatorname{Iraq}(2008) * * *$ & 7.0 & 0.66 & 0.37 & 0 & 98.97 \\
\hline $\operatorname{Iraq}(2012) * * *$ & 5.0 & 2.0 & 0.5 & 0 & 97.5 \\
\hline $\operatorname{Iraq}(2013) * * *$ & 5.5 & 2.1 & 0.6 & 0 & 97.3 \\
\hline
\end{tabular}


Source: Prepared by the researcher, *ASOSAI report 2010, ** Supreme Audit Board report 1994, *** Ministry of Finance \& Ministry of Planning, Baghdad, Iraq (2009), (2012) and (2013).

This table indicates that taxes do not play a significant role in providing financial resources to the state of Iraq and are mainly used as an effective method to tackle disparities in income levels of the citizens which are the objective of the tax laws in Iraq. Prior to 2005, all Iraqi state employees at were tax exempt. The decrease in tax revenue as a percentage of total revenue, during the past decade (from 1993 as shown in Table 1) preceding the economic sanction imposed on Iraq since 1990, is due to increased dependence on oil revenues (increasing at oil price) and exemptions of income taxes for all Iraqi governmental employees.

Table 2 illustrates that the percentage of tax revenues relative to both the general state budget and G.D.P.. The table illustrates the decline from 1986 to 1993, increasing thereafter although it still did not reach the levels of 1993 by 2008 and 2012. In 2013 the estimated budget shows that oil revenue is in Iraqi Dinars (ID) $(120,165,300,000,000$ ID) or in US\$ $(\$ 101,835,000,000)$ on the base $3,100,000$ barrel per day at $\$ 90$ per barrel. The percentage of tax revenue to oil revenue in 2012 is equal to $3.2 \%$. Non-oil revenues will contribute less than $8 \%$ of the total public revenues in 2012, and reflects the dominance of oil revenues on public revenues and the low contribution of non-oil activities. However, withholding support for public sector industrial projects puts a significant constraint on economic development in the country's strategic direction. Since industrial development is the key to any subsequent development in other economic sectors, this leads to diversification of income sources.

The expected increase in tax revenues in obtaining tax revenues from foreign oil companies, (2013 estimated 360 billion ID). The corporate income tax rose from 250 billion ID in 2011 to 304 billion ID in 2012, and to 370 billion in 2013 a change of over 21 percent for both 2012 and 2013. Most of deficit in Iraqi budget is related to operating budget. The shortage of investment budget is another reason. In general there is a lack of foreign investment due to security situation in general and to political conflict position especially between different parties.

The complex tax laws in Iraq and the lack of appropriate management systems in the emergence of the tax difficulties prevent the measure adequate revenue to fund important services provided by the government without a large deficit in the general budget and the consequent effects on the macroeconomic level.

Table (2) Percentage of tax revenue to Expenditure and GDP

\begin{tabular}{|c|c|c|c|c|c|}
\hline $\begin{array}{l}\text { Year } \\
\text { (1) }\end{array}$ & $\begin{array}{l}\text { Tax revenue } \\
\text { (ID million) } \\
(2)\end{array}$ & $\begin{array}{l}\text { Expenditure budget } \\
\text { of state } \\
\text { (ID million) } \\
\text { (3) }\end{array}$ & $\begin{array}{l}\text { Percentage of } \\
\text { (2) to (3) } \\
\text { (4) }\end{array}$ & $\begin{array}{l}\text { G.D.P. (ID million) } \\
\text { (5) }\end{array}$ & $\begin{array}{l}\text { Percentage of } \\
\text { (2) to (5) } \\
\text { (6) }\end{array}$ \\
\hline 1966 & 68.1 & 158.6 & 42.9 & 864.4 & 8.0 \\
\hline 1976 & 179.8 & $1,387.7$ & 13.0 & $4,696.8$ & 3.8 \\
\hline 1986 & 985.0 & $3,854.0$ & 25.6 & $13,086.0$ & 7.5 \\
\hline 1993 & $2,594.0$ & $6,877.0$ & 37.7 & $128,300.0$ & 2.3 \\
\hline 2008 & $728,800.0$ & $56,256,000.0$ & 13.0 & $10,411,429.0$ & 7.0 \\
\hline 2011 & $5,963,822.0$ & $64,022,625.0$ & 9.2 & $84,136,000.0$ & 7.1 \\
\hline 2012 & $8,190,200.0$ & $117,500,000.0$ & 7.0 & $163,872,400.0$ & 5.1 \\
\hline $2013^{*}$ & $9,620,000.0$ & $138,000,000.0$ & 7.0 & $184,000,000.0$ & 5.3 \\
\hline
\end{tabular}

Source; Prepared by the researcher, Ministry of finance, Annual Reports, 1967, 1977, 1994, 2009, 2011,2012 and 2013* (Estimated Budget) Baghdad, Iraq. ID= Iraqi Dinar, (Each 1\$=1180 ID in 2008) (Normally 1 ID = 3.3 US\$ before 1993).

In 2008 tax revenues from various sources totaled more than 0.7 a trillion Iraqi dinar, around \$ 530 million, an increase of 16 percent from the previous year. While in 2012 there is more improvement about 37\% from 2011, but taxes still account for just a tiny fraction of government revenue in a state almost entirely reliant on oil.

Taxes include personal and corporate income taxes, excise taxes, and tariffs. Other revenues include social contributions - such as payments for social security and hospital insurance - grants, and net revenues from public enterprises. Normalizing the data, by dividing total revenues by GDP, enables easy comparisons across countries, and provides an average rate at which all income (GDP) is paid to the national level government for the supply of public goods and services.

\section{Audit organizations}

\subsection{The Board of Supreme Audit (BSA)}

Diwan of Financial Control is the Arabic name of the Board of Supreme Audit (BSA). The date of its foundation was 1927, when the first Iraqi state audit department was established as a very small department). In 1968, law no. 42 was issued to establish BSA as an independent department of the executive, to give it powers to act on behalf of the legislature, to audit the accounts and review the accounting systems, and to act as a financial 
controller of the state enterprises. The phrase, "financial controller", as applied to BSA, does not mean that they are engaged in the day to day management of the state enterprises. Their role is that of an outside monitoring body examining such matters as the budget.

In 1980, a new law (no. 194) was issued superseding law no. 42. The new law gave the BSA more power and authority to execute its activities and to play a bigger role in the economy. It made the department responsible for financial control in Iraq; therefore, its chairman has been directly linked to the President of the Revolution Command Council. It issues financial and accounting instructions which have to be followed by the accountants in state enterprises, mixed capital companies and all foreign companies. It is the department responsible for the practice and control of the unified accounting system, according to the resolution no. 1260 in 1982. Also, it has the authority to penalize and prosecute offenders.

In 1990, a new law (no. 6) was issued granting more power to evaluate the performance of state enterprise. The main objectives are:

1. To audit all the state enterprises, mixed and foreign companies.

2. To provide technical assistance to all state enterprises in the fields of accountancy, administration, and organization.

3. To evaluate the performance and efficiency of state enterprises to ensure the correct procedures in using their economic resources.

Now, the BSA is linked to the Parliament and has the same objectives and power. Its annual financial reports are presented to the parliamentary financial committee. The president of BSA has two deputies. Each deputy is responsible for three auditing sectors. Each sector controls a number of ministries and directorates, examples of which are the Finance Ministry and Central Bank.

Each sector is responsible for the external financial assessment of the enterprises in its field and has groups of officials to carry out its duties. If the enterprise administration does not respond to the audit report the matter is reported to the concerned Minister, and if the Minister also fails to respond, the matter is reported to the Prime Minister. The follow up procedure of an audit report is very strict (such as invite the Minister to the Parliament). 5.2 The Commission of Integrity (COI)

The Commission of Integrity (COI) is an innovation occupation office and an independent governmental body that is responsible for fighting corruption. It was established in Iraq as the Commission on Public Integrity (CPI), pursuant to a statute promulgated by Iraq Governing Council and according to delegation of the dissolved Coalition Provisional Authority (CPA) in order 55 of 2004. In 2005, the Iraqi permanent constitution considered the CPI an independent commission, subject to the Parliament and changed its name to the Commission of Integrity (COI). This change was made through article 102, which states " High Commission for Human Rights, High Independent Electoral Commission and Commission of Integrity are, hereby considered an independent authority, subjected to the Iraqi Parliament and the law of Iraq “.

The COI is designed to prevent corruption, using legal means in implementing its function as a high authority consistent with section (3) of the law annexed to 2004 order 55 to work, as appropriate, for any investigation purposes. It is divided into two primary areas:

1. Legal - This area has four responsibilities: 1) investigating corruption cases by investigator under a judge; 2) proposing legislations for the purpose of fighting corruption and fostering the culture of integrity, honesty, transparency, accountability and submission to questioning and fair dealing with government; 3) to require Iraqi officials to disclose their financial status; and 4) to promulgate code of conduct for public sector employees.

2. Educational, informative and instructive - This area is responsible for developing curriculums to align ethical values, in coordination with the Ministry of Education and the Ministry of Higher Education; preparing research and studies; training; media campaign and mass communication activities; holding symposiums; educating public sector employees and ordinary people (this includes supporting their demands, through transparency, accountability and investigation).

The Commission consists of six directorates: investigations, Legal affairs, prevention, education and public relations, Non-governmental organizations, and administration. The Commission is chaired by a commissioner, which is a Minister-level position appointed by the Prime Minister. The commissioner may not be removed, unless his removal is approved by the Parliament- a provision which is applicable to cabinet ministers. The Commission has one deputy commissioner, which is a deputy minister position. The COI is acting under article (6) and (36) of UN Convention against Corruption that Iraq has verified, according to law 35 of 2007.

Normally many countries have a three-tier system of raising revenues (ASOSAI report, 2010): (a) federal taxes and non-tax sources, (b) state/provincial taxes and non-tax sources, and (c) local taxes and non-tax sources. In Iraq, revenues are raised through legislatures such as:

- The State General Budget Law.

- The General Accounting Law.

- Taxation Laws. 
- Customs Law.

- Companies Law.

- The Distribution of Profits of Public Economic Enterprises Law.

- Other Laws.

Revenue auditing in Iraq is subject to the law of the Board of Supreme Audit (No. 6 in 1990) and other laws like the General Accounting Law and the General State Budget Law. Auditing of government revenues aims to review and evaluate the results of the implementation of revenue policies and plans. Governmental revenues are audited with reference to the revenue laws. However, auditors must keep abreast of the following factors:

- Emergence of new sources of revenue and the decline/ abandonment of old ones.

- Change of different revenue resources in keeping with the economic and political changes.

The audit process is completed in accordance with accountancy standards and principles. Bodies in charge of auditing are authorized to have access to all files concerned with revenues including, review such files, and issue appropriate, related financial statements.

In fact, the financial control of public revenue is very much a concern of the Board of Supreme Audit. Accordingly procedures of checking, auditing and reviewing are devised to examine the procedures followed by the various administrative units to achieve their aims and suggest appropriate measures to avoid deficiencies that might prevent them from achieving these aims. These procedures are also used to identify systematic weaknesses and individual errors.

5.3 Audit Procedures and Methodologies in Revenue Audit

The methodologies and techniques of revenue audit have evolved over time depending on the local circumstances. The methodologies have been designed to achieve the objectives provided in the audit mandates:

- The object of receipt audit is to seek evidence that revenue is assessed and collected according to law and errors of omission and commission are avoided. It also seeks assurance that pre and post control systems (described later) operate efficiently and in accordance with the stated objectives in the sovereign and subordinate legislations.

- The collection and accounting system of government revenues are checked in audit to assess whether internal procedures and controls adequately provide for regular accounting of collection and allocation and credit of the collections to the government account.

Despite the variation in the nature and extent of different government revenues, the Board of Supreme Audit in Iraq follows a comprehensive auditing system, which could be summarized as follows:

A) Compliance Audit

This kind of audit control examines the compliance to laws and instructions to estimate, realize, collect, and deposit the revenues and also checks out that revenues are accounted, recorded, obtained, and classified in accordance with accountancy standards and principles. This audit has two facets:

i) Legitimacy auditing - determines the compliance with law and instructions.

ii) Financial auditing - determines the compliance with known accounting principles followed in applying, classifying, and summarizing financial procedures to be explained within the financial data

\section{B) Performance (Operational) Auditing}

This is the most important type of auditing practiced by the Board of Supreme Audit. This includes all financial and non - financial aspects to assure the soundness of statements and the extent of achieving the desired objects of institutions and their laws. Article 3 of the law of the Board of Supreme Audit provides for an annual plan for performance audit. There was a study under way to evaluate the performance of the tax system in Iraq under the annual audit plan of 2011, as well as the previous two years.

In Canada, the scope of performance audit includes the examination of economy, efficiency, cost-effectiveness, and environmental effects of government activities; procedures to measure effectiveness; accountability relationships; protections of public assets; and compliance with authorities. The subject of the audit can be a government entity or activity (business line), a sectoral activity, or a government-wide functional area (OAG, 2005). Similarly, in Iraq, performance auditing consists of many procedures which seek to examine:

i. The efficiency of the internal control systems and the effectiveness of other systems and the financial procedures and employee understanding of these systems and procedures and their capabilities to achieve the task;

ii. The efficiency, adequacy, and comprehensiveness of the accounting system in the administrative unit;

iii. The efficiency of data which are produced by the system to meet the user needs in different administrative levels related to planning, implementation, follow-up, and control; and

iv. The efficiency of the laws and legislations (i.e. whether the objects and financial policies are clear).

5.4 Audit Planning

The Board of Supreme Audit in Iraq prepares an annual general plan of its work and specific plans for different 
sectors. The Board has specific plans for offices such as Income tax, Customs, etc. These plans are prepared according to scientific norms depending on the available audit resources. While implementing the audit plans, the Board ensures that the objects of the plan are administered in an effective and efficient manner while supporting routine activities related to the audit, review, and follow-up. The Board seeks assurance:

i. That the auditees have achieved the policy and program objectives;

ii. That treatment and classification of the revenues were done according to the established accounting standards; and

iii. That the related instruction, systems and laws have been applied to the fullest extent.

5.5Auditing Methods for Government Revenues

The main duty of Board of Supreme Audit is preparing a report in which it explains its opinion about the results of the audit statements according to the produced facts and data. The Board follows several methods of audit checks according to the nature of its work:

i. The pre-control - this task is achieved according to the law and a previous agreement of higher authority in Iraq.

ii. The periodic (immediate) control - the control institutions check the accounts in the same year.

iii. The post-control - the Board's checking during the post - control process focuses on the two operational stages:

a) The estimation stage - this task is done by the technical departments to check and determine tax.

b) The implementation, levying, and collection stage - this is done by the department responsible for levying and collection of tax.

\subsection{Human Resource Management}

BSA membership exceeds 1700 auditors which cover all the state. Revenue audit has been accepted as a specialized area requiring adequate skill formation and ongoing improvement. Most of the BSA members are responsive to the training needs in this area and are trying to develop or have developed strong task forces to carry out an effective mission in this branch of audit. Various internal and external training courses and workshops are organized by the BSA and the University of Baghdad through the creation of a diploma program in auditing. In order to equip the work force with the necessary theoretical and empirical inputs, this program takes three years to complete

Since revenue audit is largely a legalistic audit, the complexities and nuances of the tax laws and case laws have to be clearly understood and appreciated by auditors for any meaningful analysis. Maintenance of a properly documented and accessible system of case laws, national and international, is necessary to keep the knowledge and information current. In addition, it is necessary to present many conferences and workshop in many countries.

Stages of the auditing process and the role of the specialized departments in the tax offices are as follows:

A. Audit checking of the technical department

- To realize the efficiency of internal control systems

- To ascertain how far the tax estimates are accurate

- To insure that tax estimates are fair and based on a sound footing and on adequate data

- To ensure the soundness of tax procedures

- To ensure that procedures are being followed properly

B. For departments engaged in collection of revenues, the following checks are applied:

- To ensure that all revenues are collected during the financial period in fact represents all the revenues which are due for collection during the period under the laws.

- The compare the actual collections with the budget estimate.

- To analyze the reasons for arrears in collection.

- To assure that all revenues are deposited in the banks accounts.

- To ensure that all records (journal, ledgers) have been fixed by law.

- To ensure that the system for collection of revenues is working efficiently.

- To ensure that demand notices have been issued to the tax payers.

- To ensure that proceedings have been initiated against tax defaulters.

C. Questionnaire on Internal Control - This method is used for obtaining accurate information related to the soundness of financial procedures to check the following points:

- The extent of soundness of the accounting and financial systems and the adequacy of the records used by tax offices

- The soundness of the internal control systems which help determination of the size of the sample of audit

- To ensure that the procedures related to collection of revenues and other procedures are accurate 


\section{Discussion}

Government revenues increased as global oil prices remained persistently high for much of 2012. Iraq's contracts with major oil companies have the potential to further expand oil exports and revenues, but Iraq will need to make significant upgrades to its oil processing, pipeline, and export infrastructure to enable these deals to reach their economic potential. The task of rebuilding the country after 2003 remains immense and is made harder by sectarian politics and prolonged violence. Iraq's reconstruction requires not only the rebuilding of its infrastructure, but also of its economic and social institutions and the creation of a business environment that attracts capital and brings with it new technology and skills to modernize the economy. Iraq's huge oil reserves could, in principle, provide the revenues needed to finance the reconstruction, but strong institutions and favorable business environment are needed to use these resources effectively. The longer-term outlook is strong as domestic and foreign investment in the hydrocarbon sector is bearing fruit. According to the Ministry of Oil, oil production reached 3.3 million barrels per day (mbpd), of which $2.6 \mathrm{mbpd}$ are exported, and extraction and exports are projected to increase considerably in the years ahead. Nevertheless, Iraq's economic prospects continue to be subject to significant risks, deriving mainly from institutional and capacity constraints, oil prices volatility, delays in the development of oil infrastructure, and an extremely fragile political and security situation. From 2009, parliament took an unprecedented step and indicted some government ministers through the Integrity Committee and utilizing financial reports. The following years have been showed many invitations to Prime Minister and Ministers in Parliament. The interesting situation was the Minister of Trade whose indictment was televised as when he was accused of corruption, arrested, and imprisoned. However, due to the political influence of his party, they have trying to smuggle him outside of the country, but was captured him at airport. Another example of corruption was the case of the Minister of Electricity. He was smuggled from the country because of his US nationality.

The role of the parliament should be changed to promote and encourage the implementation in a particular type of accountability informed by new public management (for instance the Inspector General of each ministry).

Parliament has begun to take important steps in limiting corruption. However, it needs to assume a larger role and increase its power in order to educate politicians and the leading political parties about the merits of the accountability system. It must also give more attention to governmental auditing reports and issue strict instructions to rein in the corruption. Table 3 show the influence of country-wide corruption by presenting the audit results from the Commission of Integrity in 2009. Table 4 show the influence of corruption in the capital (Baghdad) by presenting the audit results from the Commission of Integrity in 2009.

Table 3: No. of forms checked and Bribes Detected by the Commission of Integrity in Iraq 2009:

\begin{tabular}{|c|c|c|c|c|c|c|}
\hline MONTH & $\begin{array}{l}\text { NO. OF } \\
\text { FORMS } \\
\text { CHECKE } \\
\text { D }\end{array}$ & $\begin{array}{l}\text { NO. OF } \\
\text { PAYING } \\
\text { BRIBER } \\
\text { Y }\end{array}$ & $\begin{array}{l}\% \\
\text { Bribes } \\
\text { Detected }\end{array}$ & $\begin{array}{l}\text { ACCUMULAT } \\
\text { D NO. OF } \\
\text { FORMS } \\
\text { CHECKED }\end{array}$ & $\begin{array}{l}\text { ACCUMULATE } \\
\text { D NO. OF } \\
\text { PAYING } \\
\text { BRIBERY }\end{array}$ & $\begin{array}{l}\% \quad \text { BRIBES } \\
\text { DETECTED } \\
\text { (ACCUMULATED } \\
\text { ) }\end{array}$ \\
\hline June & 10,641 & 2,197 & $20.65 \%$ & 10,641 & 2,197 & $20.65 \%$ \\
\hline July & 8,059 & 1,533 & $19.02 \%$ & 18,700 & 3,730 & $19.95 \%$ \\
\hline August & 7,561 & 1,378 & $18.32 \%$ & 26,261 & 5,108 & $19.45 \%$ \\
\hline $\begin{array}{l}\text { Septembe } \\
\mathrm{r}\end{array}$ & 9,653 & 1,438 & $14.90 \%$ & 35,914 & 6,546 & $18.23 \%$ \\
\hline October & 15,563 & 2,145 & $13.78 \%$ & 51,477 & 8,691 & $16.88 \%$ \\
\hline $\begin{array}{l}\text { Novembe } \\
\mathrm{r}\end{array}$ & 16,647 & 1,905 & $11.44 \%$ & 68,124 & 10,596 & $15.55 \%$ \\
\hline December & 14,815 & 1,533 & $10.35 \%$ & 82,939 & 12,129 & $14.62 \%$ \\
\hline
\end{tabular}

Source: Commission of integrity report, 2010, Baghdad, Iraq.

Table 3 above provides a summary of the ratios of the extent of bribery detected by the Commission of Integrity in Iraq during 2009. The table indicates that the percentages of detected bribes reduced from $20.65 \%$ in June to $10.35 \%$ in December (20.65\% to $14.62 \%$ in accumulated form for the period from June to December). Results summarized in Table 3 for Iraq or consistent with the results provided in Table 4 indicating a reduction of detected bribes in the capital Baghdad from 35.79\% in April to 4.97\% in December $(35.79 \%$ to $9.84 \%$ in accumulated form). 
Table 4: No. of forms checked and Bribes Detected by the Commission of Integrity in Baghdad 2009:

\begin{tabular}{||l|l|l|l||l|l|l||}
\hline \hline MONTH & $\begin{array}{l}\text { NO. OF } \\
\text { FORMS } \\
\text { CHECKED }\end{array}$ & $\begin{array}{l}\text { NO. OF } \\
\text { PAYING } \\
\text { BRIBER } \\
\text { Y }\end{array}$ & $\begin{array}{l}\text { \%Bribes } \\
\text { Detected }\end{array}$ & $\begin{array}{l}\text { ACCUMULATE NO. OF } \\
\text { FORMS } \\
\text { CHECKED }\end{array}$ & $\begin{array}{l}\text { ACCUMUL } \\
\text { ATED NO. } \\
\text { OF } \\
\text { PAYING } \\
\text { BRIBERY }\end{array}$ & $\begin{array}{l}\text { BRIBES } \\
\text { DETECTED } \\
\text { ACCUMULAT } \\
\text { ED) }\end{array}$ \\
\hline April & 897 & 321 & $35.79 \%$ & 897 & 321 & $35.79 \%$ \\
\hline May & 1,773 & 445 & $25.10 \%$ & 2,670 & 766 & $28.69 \%$ \\
\hline June & 3,445 & 475 & $13.79 \%$ & 6,115 & 1,241 & $20.29 \%$ \\
\hline July & 3,338 & 568 & $17.02 \%$ & 9,453 & 1,809 & $19.14 \%$ \\
\hline August & 3,883 & 381 & $9.81 \%$ & 13,336 & 2,190 & $16.42 \%$ \\
\hline September & 4,919 & 404 & $8.21 \%$ & 18,255 & 2,594 & $14.21 \%$ \\
\hline October & 7,466 & 542 & $7.26 \%$ & 25,721 & 3,136 & $12.19 \%$ \\
\hline November & 6,777 & 379 & $5.59 \%$ & 32,498 & 3,515 & $10.82 \%$ \\
\hline December & 6,505 & 323 & $4.97 \%$ & 39,003 & 3,838 & $9.84 \%$ \\
\hline \hline
\end{tabular}

Source: Commission of integrity report, 2010, Baghdad, Iraq

\section{Findings, Limitations, Further Studies and Conclusions}

Revenue audit has been recognized as an important area that requires greater attention and more specialization. In this era of trade globalization and shift to a market economy, every country will be opening avenues of investment. Governments' fiscal policies and laws will in turn tend to change according to the new economic environment. Consequently audit will have to adapt itself to the changed pattern of government revenues and define its auditing standards according to further studies.

For example, a Value Added Tax (VAT) may replace the existing indirect taxes in Iraq and a liberalized tax regime may reduce the tax rates to attract investments without reducing the share of government revenues. Audit will have a role to play in ensuring that appropriate tax laws are in place to translate the changes and also to assure laws are implemented properly to safeguard government revenues in an era of liberalization. Information Technology (IT) audit is another area of challenge which will have its own momentum of development in a new Iraq.

The Central Bank has successfully held the exchange rate at about 1,180 Iraqi dinars/US dollar since January 2009. Inflation has remained under control since 2006 as security improved. However, Iraqi leaders remain hard pressed to translate macroeconomic gains into an improved standard of living for the Iraqi populace. Unemployment remains a problem throughout the country despite a bloated public sector. Encouraging private enterprise through deregulation would make it easier for Iraqi citizens and foreign investors to start new businesses. Rooting out corruption and implementing reforms - such as restructuring banks and developing the private sector - would be important steps in this direction.

The government should encourage develop countries to invest in Iraq in different sectors and not in oil sector only, by issuing the law of infrastructure, which parliament rejected according to the political conflicts. Therefore, political differences may delay many useful laws in parliament.

The main conclusions that can be drawn from this study relate to government revenues in Iraq. Government revenues depend totally on oil revenues in spite of increasing tax revenues. It is clear from Table 1 that government revenues in Iraq do not reflect the situation in developing countries. The auditing rules are sufficient enough for the existing situation, but there will be a need to improve the new kinds of government revenues such as VAT and IT. The researcher recommends that the parliament increase its role in ensuring that most government expenses are legal and far from financial and managerial corruption. Parliament should create and support new control bodies to oversee the new revenues and expenditures. It should also activate a role related to state taxes and reduce exemptions.

\section{References}

The Asian Organization of Supreme Audit Institution. 2010. ASOSAI Report. Retrieved from

http://www.raa.gov.bt/contents/whats-new/gov-revenue.php.

Barton, A. D. 2000. "Accounting for public heritage facilities - Assets or liabilities of the government", Accounting, Auditing \& Accountability Journal, 13(2), 219 -36.

Beechy, T. H. 2007. Does full accrual accounting enhance accountability? The Innovation Journal, 12(3), article 4.

The Board of Supreme Audit, Law No. (6) 1990, Iraqi official newspaper (Alwqaa al Iraqi) 
number: 3293 | Date: 02/05/1990, Baghdad, Iraq (Arabic). Retrieved from http://www.iraq-ild.org/ The Board of Supreme Audit, Annual Report, Baghdad, Iraq, (Unpublished reports) 19942002, 2007-2008.

Earl, L. 2005. From accounting to accountability: Harnessing data for school improvement, Research Conference 'Using Data to Support Learning' 1/1/2005. Retrieved from http://research.acer.edu.au/research_conference_2005/8/.

Earl, L., \& P. LeMahieu. 1997. Rethinking assessment and accountability. In a hargreaves (Ed.), Rethinking Educational Change with Heart and Mind. 1997, ASCD Yearbook. Alexandria VA.

Elsayed, M, O,\& Z. Hoque. 2010. Perceived international environmental factors and corporate voluntary disclosure practices: An empirical study. The British Accounting Review, 42(1), 17-35.

Gendron, Y., Cooper, D. J, \& B. Townley. 2001. In the name of accountability - State auditing, independence and new public management, Accounting, Auditing \& Accountability Journal, Vol. 14(3), 278-310

Kloot, L. 1999. Performance measurement and accountability in Victorian local Government, International Journal of Public Sector Management, 12(7), 565-84

Ministry of Finance, Annual reports, 1967, 1977, 1987, 1994, 2008 and 2011 (Estimated Budget), Ministry publications, Baghdad, Iraq.

Ministry of Planning, Annual Statistics Reports, 1994-2000, Ministry publications, Central library, Baghdad, Iraq,

Office of the Auditor General of Canada (OAG). 2005. Performance Audit Manual. Ottawa, Canada: Minister of Public Work and Government Services, June. Retrieved from http://www.oag-bvg.gc.ca/internet/english/meth lp e 29337.html.

Perks, R., \& R. Glendinning. 1981. Performance indicators applied to the nationalised industries, Management Accounting, October, 22-24.

Pollitt, C.J. 1993. Audit and accountability: The missing dimension? Journal of Royal of Medicine, 86(April), 209-11. 
The IISTE is a pioneer in the Open-Access hosting service and academic event management. The aim of the firm is Accelerating Global Knowledge Sharing.

More information about the firm can be found on the homepage:

http://www.iiste.org

\section{CALL FOR JOURNAL PAPERS}

There are more than 30 peer-reviewed academic journals hosted under the hosting platform.

Prospective authors of journals can find the submission instruction on the following page: http://www.iiste.org/journals/ All the journals articles are available online to the readers all over the world without financial, legal, or technical barriers other than those inseparable from gaining access to the internet itself. Paper version of the journals is also available upon request of readers and authors.

\section{MORE RESOURCES}

Book publication information: http://www.iiste.org/book/

Recent conferences: http://www.iiste.org/conference/

\section{IISTE Knowledge Sharing Partners}

EBSCO, Index Copernicus, Ulrich's Periodicals Directory, JournalTOCS, PKP Open Archives Harvester, Bielefeld Academic Search Engine, Elektronische Zeitschriftenbibliothek EZB, Open J-Gate, OCLC WorldCat, Universe Digtial Library, NewJour, Google Scholar

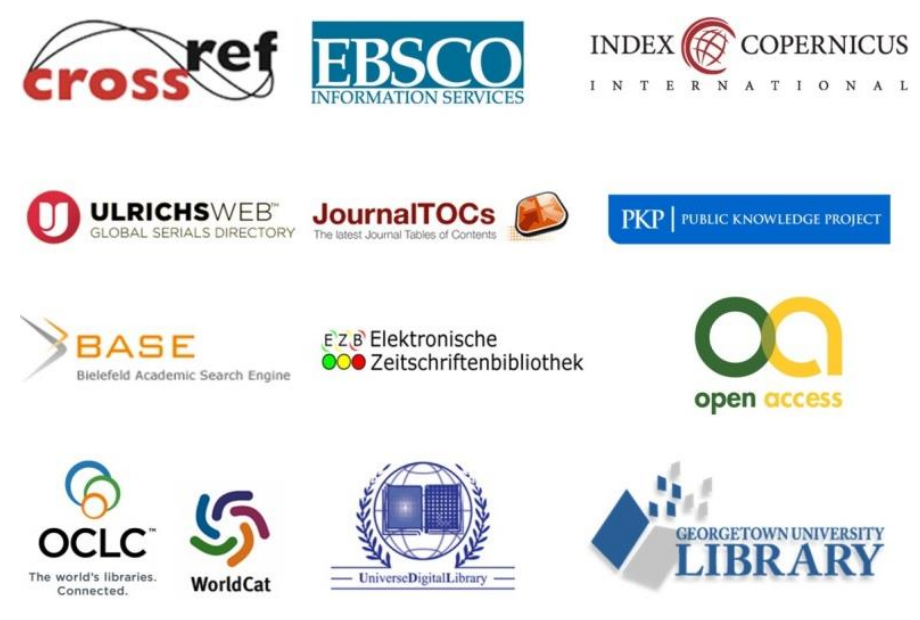

